\title{
Changes of lipolytic enzymes cluster with insulin resistance syndrome
}

\author{
P. Knudsen ${ }^{1}$, J. Eriksson ${ }^{1}$, S. Lahdenperä ${ }^{1}$, J. Kahri ${ }^{1}$, L. Groop ${ }^{2,3}$, M.-R. Taskinen ${ }^{1}$ and the Botnia Study Group \\ ${ }^{1}$ Third Department of Medicine, University of Helsinki, Helsinki, Finland \\ ${ }^{2}$ Fourth Department of Medicine, University of Helsinki, Helsinki, Finland \\ ${ }^{3}$ Department of Endocrinology, University of Lund, Malmö General Hospital, Malmö, Sweden
}

Summary The activities of hepatic and lipoprotein lipase and the levels of lipo- and apoproteins were compared in two groups of normoglycaemic men representing the highest $(n=18)$ and lowest $(n=15)$ fasting insulin quintiles of first degree male relatives of non-insulin-dependent diabetic patients. The high insulin group representing insulin-resistant individuals had significantly lower post-heparin plasma lipoprotein lipase activity than the low insulin group $\left(14.2 \pm 4.0\right.$ vs $20 \pm 5.8 \mu \mathrm{mol} \quad \mathrm{NEFA} \cdot \mathrm{ml}^{-1} \cdot \mathrm{h}^{-1}$, $p<0.001$; hepatic lipase activity did not differ between the two groups $(24.2 \pm 11$ vs $18.0 \pm 5.3 \mu \mathrm{mol}$ $\left.\mathrm{NEFA} \cdot \mathrm{ml}^{-1} \cdot \mathrm{h}^{-1}, \mathrm{NS}\right)$. The lipoprotein lipase/hepatic lipase ratio in the high insulin group was decreased by $66 \%$ as compared to the low insulin group $(0.75 \pm 0.57$ vs $1.25 \pm 0.65, p<0.01)$. In the high insulin group both total and VLDL triglycerides were higher than in the low insulin group $(1.61 \pm 0.57$ vs $0.86 \pm 0.26 \mathrm{mmol} / 1, \quad p<0.001$ and
$1.00 \pm 0.47$ vs $0.36 \pm 0.16 \mathrm{mmol} / 1, p<0.001$, respectively) whereas $\mathrm{HDL}$ cholesterol and $\mathrm{HDL}_{2}$ cholesterol were lower $(1.20 \pm 0.30$ vs $1.43 \pm 0.22 \mathrm{mmol} / \mathrm{l}$, $p<0.05$ and $0.49 \pm 0.21$ vs $0.71 \pm 0.17 \mathrm{mmol} / \mathrm{l}$, $p<0.05$, respectively). Total cholesterol, LDL cholesterol or $\mathrm{HDL}_{3}$ cholesterol did not differ between the two groups. The mean particle size of LDL was smaller in the high insulin group than in the low insulin group ( $258 \pm 7$ vs $265 \pm 6 \AA, p<0.05)$. We propose that the changes of lipoprotein lipase and lipoprotein lipase/hepatic lipase ratio cluster with insulin resistance and provide a possible mechanism to explain the lowering of HDL cholesterol and elevation of triglyceride concentrations observed in insulin-resistant subjects. [Diabetologia (1995) 38: 344-350]

Key words Insulin resistance, lipase activities, lipoproteins.
The metabolic syndrome, also referred as insulin resistance syndrome (IRS), is recognized as a common risk factor for coronary heart disease [1-3]. Dyslipidaemia, characterized by the elevation of triglyce-

Received: 18 May 1994 and in revised form: 30 August 1994

Corresponding author: Professor M.-R. Taskinen, Third Department of Medicine, University of Helsinki, Haartmaninkatu 4, FIN-00290 Helsinki, Finland

Abbreviations: LPL, Lipoprotein lipase; HL, hepatic lipase; VLDL, very low density lipoprotein; IDL, intermediate density lipoprotein; LDL, low density lipoprotein; HDL, high density lipoprotein; chol, cholesterol; TG, triglycerides; NEFA, nonesterified fatty acids. rides and lowering of HDL-cholesterol, is an inherent feature in this cluster of metabolic abnormalities which also include insulin resistance, hyperinsulinism, central obesity, impaired glucose tolerance or non-insulin-dependent diabetes mellitus (NIDDM) and hypertension. Recently, the preponderance of small dense LDL has been linked with this constellation $[4,5]$. The lipoprotein pattern has been termed as the atherogenic lipoprotein phenotype and it is associated with excess risk of coronary heart disease $[6,7]$.

A major challenge is to define the causal sequence between dyslipidaemia and insulin resistance. Several studies have demonstrated that fasting insulin is related to high triglyceride levels [8-11]. Substantial evidence indicates that hypertriglyceridaemia is indeed 
associated with insulin resistance measured by euglycaemic clamp $[10,12,13]$. In insulin resistant states VLDL production in liver is enhanced and considered to be the major cause for the elevation of serum triglycerides $[1,14]$. It is also well-recognized that insulin has multiple sites of action on the assembly and secretion of VLDL particles $[15,16]$. The question is still unresolved whether hyperinsulinaemia per se is the driving force for increased production of VLDL, or if a disruption of the co-ordinated regulation of apo $B$ leads to increased VLDL secretion [17]. Interestingly, recent kinetic data indicate that insulin resistance in obese subjects interferes with the normal inhibitory action of hyperinsulinaemia on VLDL triglyceride and apo B metabolism [18].

Since LPL, which is the key enzyme in hydrolysis of triglyceride-rich particles, is an insulin-sensitive enzyme it is attractive to speculate that insulin resistance may also influence lipoprotein lipase (LPL). Pykälistö et al. [19] were the first to report that postheparin plasma and adipose tissue LPL activity are reduced in NIDDM subjects. Interestingly, the response of post-heparin LPL to hyperinsulinaemia is blunted in obese subjects, suggesting that the enzyme is insulin resistant [20-22]. Recently Pollare et al. [23] reported that the glucose infusion rate during a clamp study which is a parameter of insulin sensitivity, explains to a significant degree the variations in post-heparin plasma LPL activity, and particularly in muscle LPL activity. Generally, in insulin resistance the lowering of LPL activity would impede VLDL clearance and also result in lowering of HDL.

The variation in plasma HDL is also determined by hepatic lipase (HL) [24]. In contrast to LPL activity, HL activity has been reported to be increased in insulin-resistant states such as NIDDM and obesity [25-27]. Elevated HL activity is common in individuals with hypertriglyceridaemia and low HDL cholesterol. Blades et al. [28] propose that low LPL/HL ratio could be one underlying mechanism for lowering of HDL cholesterol in this patient group. Likewise, Lamarche et al. [29] reported that subjects with high triglycerides and low HDL cholesterol concentrations had lower post-heparin plasma LPL/HL ratio and showed hyperinsulinaemia which is indicative of insulin resistance. Overall, a net result of opposite changes of LPL and HL in insulin resistance states would be lowering of HDL.

Glucose-tolerant first degree relatives of NIDDM patients have genetic susceptibility to develop NIDDM and they manifest the full profile of the insulin resistance syndrome [30-32]. Such individuals are characterized by hyperinsulinaemia as a marker of insulin resistance [32,33]. Recent observations indicate that first degree relatives of NIDDM patients also have typical alterations of VLDL and HDL although the ambient concentrations of VLDL and HDL can still be within the normal range [34]. Consequently these individuals represent an ideal cohort to study if changes of LPL and/or HL activities cluster with insulin resistance and contribute to the observed dyslipidaemia.

Therefore we recruited glucose-tolerant first degree relatives of NIDDM patients belonging either to the lowest or highest quintiles of fasting insulin to determine the activities of post-heparin plasma LPL and HL. In addition we measured the concentrations of major lipoproteins, LDL and HDL subclasses to evaluate the interrelationship between lipolytic enzymes and alterations of lipoproteins.

\section{Materials and methods}

The initial cohort represents a population of glucose-tolerant first-degree relatives of the NIDDM patients $(n=1050)$ examined between February 1990 and January 1992 in the Botnia study. All subjects had an oral glucose tolerance test (OGTT, $75 \mathrm{~g}$ glucose), which was performed in the morning after a 12h overnight fast. Glucose and insulin were determined at 0 , 30,60 and $120 \mathrm{~min}$. Male subjects $(n=505)$ with normal oral glucose tolerance according to World Health Organization criteria [35] were categorized into quintiles of fasting insulin levels. The cut-off points of the lowest and highest insulin quintiles were $4.6 \mathrm{mU} / 1$ and $10 \mathrm{mU} / 1$ (= 33 and $72 \mathrm{pmol} / 1)$, respectively.

For this study we invited a subset of 61 men selected to have similar age range and BMI belonging either to the lowest $(n=31)$ or highest $(n=30)$ quintile at the first examination. These men were examined between October 1992 and March 1993. At the second examination 28 subjects of the original groups had fasting insulin values between $4.6 \mathrm{mU} / \mathrm{l}$ and $10 \mathrm{mU} / \mathrm{l}$. To guarantee correct categorization the subjects who were not in their allocated quintiles were excluded from the study. Patients with major illnesses known to affect lipid metabolism (i.e., malignant diseases, thyroid or other endocrine disorders, renal or hepatic disorders, current infections) were excluded on the basis of laboratory tests and clinical history. Four patients were on a medication for high blood pressure.

Patients were re-examined in the participating Health Care Centers in the Botnia area. Heparin tests were performed and the blood samples collected after an overnight fast. Apart from locally determined blood glucose concentrations all the laboratory measurements were performed in the Helsinki University Hospital.

At the re-examination 15 of the 61 participants had fasting serum insulin levels below $4.6 \mathrm{mU} / \mathrm{l}$. These subjects comprised the insulin-sensitive subgroup. A total of $18 \mathrm{men}$ had fasting insulin over $10 \mathrm{mU} / \mathrm{l}$ and composed the insulin-resistant group. The two groups were close in age but the insulin-resistant group had slightly higher BMI than the insulin-sensitive group (Table 1).

Serum lipid and lipoprotein analyses. Lipoprotein fractions (VLDL, LDL and HDL) were isolated from fresh serum by sequential ultracentrifugation [36] in a Beckman L7-70 ultracentrifuge (Beckman Instruments, Palo Alto, Calif., USA) using a Kontron TZT 45.6 rotor (Kontron AG, Basel, Switzerland). VLDL and LDL were isolated at densities of 1.006 and $1.063 \mathrm{~g} / \mathrm{ml}$, respectively as described previously [37]. Thereafter, $\mathrm{HDL}_{2}$ and $\mathrm{HDL}_{3}$ were isolated at densities of 1.125 and $1.210 \mathrm{~g} / \mathrm{ml}$ by centrifugation for $48 \mathrm{~h}$ at $38,000 \mathrm{rev} / \mathrm{min}$. 
Table 1. Characteristics of the study groups

\begin{tabular}{lcc}
\hline & $\begin{array}{l}\text { Low-insulin } \\
\text { group } \\
(n=15)\end{array}$ & $\begin{array}{l}\text { High-insulin } \\
\text { group } \\
(n=18)\end{array}$ \\
\hline Age (years) & $46.1 \pm 6.6$ & $45.1 \pm 6.8$ \\
Body mass index $\left(\mathrm{kg} / \mathrm{m}^{2}\right)$ & $25.0 \pm 1.5^{\mathrm{a}}$ & $26.6 \pm 1.8$ \\
Waist/hip ratio & $0.92 \pm 0.07^{\mathrm{a}}$ & $0.97 \pm 0.04$ \\
Fasting plasma insulin $(\mu \mathrm{U} / \mathrm{ml})$ & $3.4 \pm 0.59$ & $13 \pm 2.9$ \\
Fasting blood glucose $(\mathrm{mmol} / \mathrm{l})$ & $3.7 \pm 0.4^{\mathrm{a}}$ & $4.2 \pm 0.4$ \\
Diastolic blood pressure $(\mathrm{mmHg})$ & $80 \pm 9$ & $84 \pm 7$ \\
Systolic blood pressure & $128 \pm 14$ & $132 \pm 12$ \\
\hline
\end{tabular}

Results are mean $\pm \mathrm{SD},{ }^{\mathrm{a}} p<0.05$ for difference from respective values in the high-insulin group

Table 2. Concentrations of lipids and lipoproteins in the study population groups

\begin{tabular}{lll}
\hline & $\begin{array}{l}\text { Low-insulin } \\
\text { group } \\
(n=15)\end{array}$ & $\begin{array}{l}\text { High-insulin } \\
\text { group } \\
(n=18)\end{array}$ \\
\hline $\begin{array}{l}\text { Cholesterol }(\mathrm{mmol} / \mathrm{l}) \\
\text { Total }\end{array}$ & $5.62 \pm 1.2$ & $6.09 \pm 1.0$ \\
HDL & $1.43 \pm 0.22^{\mathrm{a}}$ & $1.20 \pm 0.26$ \\
$\mathrm{HDL}_{2}$ & $0.71 \pm 0.17^{\mathrm{a}}$ & $0.49 \pm 0.21$ \\
HDL $_{3}$ & $0.73 \pm 0.12$ & $0.71 \pm 0.11$ \\
LDL $_{\text {Triglycerides }(m m o l / l)}$ & $3.80 \pm 1.1$ & $4.09 \pm 0.86$ \\
Total & $0.86 \pm 0.26^{\mathrm{b}}$ & $1.61 \pm 0.57$ \\
VLDL & $0.36 \pm 0.16^{\mathrm{b}}$ & $1.00 \pm 0.47$ \\
\hline
\end{tabular}

Results are mean $\pm \mathrm{SD},{ }^{a} p<0.05,{ }^{b} p<0.001$ for difference from respective values in the high-insulin group

Lipase analyses. Heparin (100 IU/kg body weight Leiras, Huhtamäki OY, Turku, Finland) was injected i.v. as a bolus to release lipolytic enzymes into the circulation. The blood was collected into chilled heparinized tubes before and 5 and $15 \mathrm{~min}$ after the injection and placed on ice immediately. Plasma was separated and transferred into plastic tubes which were immediately frozen at $-20^{\circ} \mathrm{C}$.

LPL and HL activities were measured using an immunochemical method described by Huttunen et al. [38]. A specific antiserum against HL was used in the LPL assay. To measure the $\mathrm{HL}$ activity a substrate containing $1 \mathrm{~mol} / \mathrm{I} \mathrm{NaCl}$ to inactivate the LPL was used. The intra-assay variation for LPL was $4.6 \%$ and for HL $5.1 \%$. The interassay variations were $5.1 \%$ and $8.4 \%$, respectively.

Analytical methods. Fasting insulin was determined by a double-antibody radioimmunoassay (Pharmacia Diagnostics AB, Uppsala, Sweden). The interassay variation was determined using two standard specimens (13 and $45 \mathrm{mU} / \mathrm{l} ; 93$ and $323 \mathrm{pmol} / \mathrm{l}$ ); the means of the determinations averaged 13.2 and $43.9 \mathrm{mU} / 1$ ( 94.5 and $315 \mathrm{pmol} / \mathrm{l})$ giving interassay variations of 7 and $4.8 \%$, respectively.

Concentrations of cholesterol and triglycerides in serum and in lipoprotein fractions were measured enzymatically using kits from Hoffman-La Roche nos.0715166 and 0722138 (Basel, Switzerland) in an automated Cobas Mira analyzer. ApoA-I and apoA-II concentrations were determined by immunoturbidometry using monospecific antibodies (nos.726478 and 726486, Boehringer Mannheim GmbH, Mannheim, Germany). The interassay variations for apoA-I and for apoA-II were $3.6 \%$ and $3.7 \%$, respectively.
The concentration of LpA-I particles was quantified by using differential electroimmunophoresis with hydrated agarose gels containing monospecific antibodies against apoA-I and apoA-II (Sebia, Issy-les Molineaux, France) as described elsewhere in detail $[39,40]$. The concentration of LpA-I:LpA-II particles was calculated by subtracting the concentration of LpA-I particles from turbidometrically determined total concentration of apoA-I in serum. Interassay variation for LpA-I particle concentration was $7.3 \%$.

To determine the mean particle diameter of the main LDL peak, non-denaturating polyacrylamide gel electrophoresis was performed from frozen serum samples, stored at $-70^{\circ} \mathrm{C}$ using the method previously described by Nichols et al. [41]. The gels with linear polyacrylamide gradient of $2-12 \%$ were cast in our laboratory according to the method of Margolis and Kenrick [42] with slight modifications. Stock solution A contained $12.0 \%$ acrylamide (bisacrylamide $5.0 \%$ ), $5.0 \%$ sucrose, $0.012 \%$ ammonium persulfate and $0.085 \%$ tetramethylethylenediamine and stock solution B contained $2.0 \%$ acrylamide (bisacrylamide $5.0 \%$ ), $0.019 \%$ ammonium persulfate and $0.120 \%$ tetramethylethylenediamine. Both stock solutions were made into $1 \% \mathrm{~mol} / \mathrm{l}$ Tris- $\mathrm{HCl}$ buffer ( $\mathrm{pH} 8.3$ ). Casting of the gels was performed by using gradient Mixer GM-1 (Pharmacia), Gel Slab Casting Apparatus GSC-8 (Pharmacia) and Peristaltic Pump P-1 (Pharmacia) as previously described [43]. The gels were stained with Sudan Black B lipid stain prepared as described previously [44]. After the destaining procedure the gels were scanned with a computer-assisted Molecular Dynamics Personal Densitometer (Sunnyvale, Calif, USA) using a 50- $\mu \mathrm{m}$ pixel size and 12-bit signal resolution. The particle diameter of the major LDL peak was determined by comparing the mobility of the sample with that of a calibrated reference LDL preparation run together on each gel. CV values were $1.8 \%$ and $1.2 \%$, respectively, for intergel and intragel precisions of the used control sample.

\section{Statistical analysis}

Statistical analyses were performed using SYSTAT version 5.0 Systat inc., Evanston, IL, USA. Comparisons between the groups were performed using analysis of variance adjusted for differences in BMI (ANCOVA) since BMI differed slightly between the groups. Univariate correlations were calculated using Pearson's correlation analyses.

\section{Results}

Table 2 compares the concentrations of blood lipids and lipoproteins in men representing either low- or high-insulin groups. Men in the highest quintile of insulin had twofold higher total and VLDL triglycerides than men in the lowest quintile and these differences were highly significant. In the high insulin group the concentration of HDL cholesterol was $16 \%$ lower $(p<0.05)$ than in the low insulin group. This difference was due to the low levels of $\mathrm{HDL}_{2}$ cholesterol whereas $\mathrm{HDL}_{3}$ cholesterol did not differ between the two groups. Subjects in the highest insulin quintile had lower levels of apoA-I than men in the low insulin group $(129 \pm 12$ vs $146 \pm 19 \mathrm{mg} / \mathrm{dl}$, $p<0.05)$ whereas the mean levels of apo A-II were similar ( $37 \pm 5$ vs $36 \pm 4 \mathrm{mg} / \mathrm{dl}$, NS). Accordingly the 


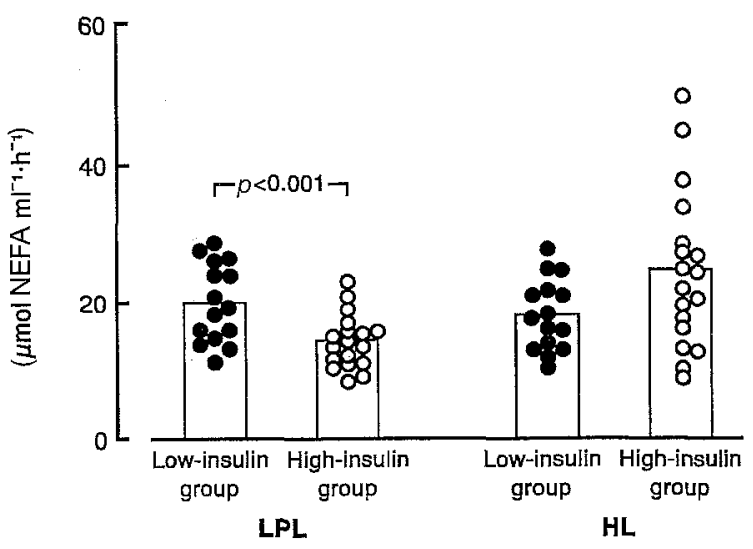

Fig. 1. Individual values of lipoprotein lipase and hepatic lipase activities in the low- and high-insulin groups. The mean of each group is marked with a solid horizontal line
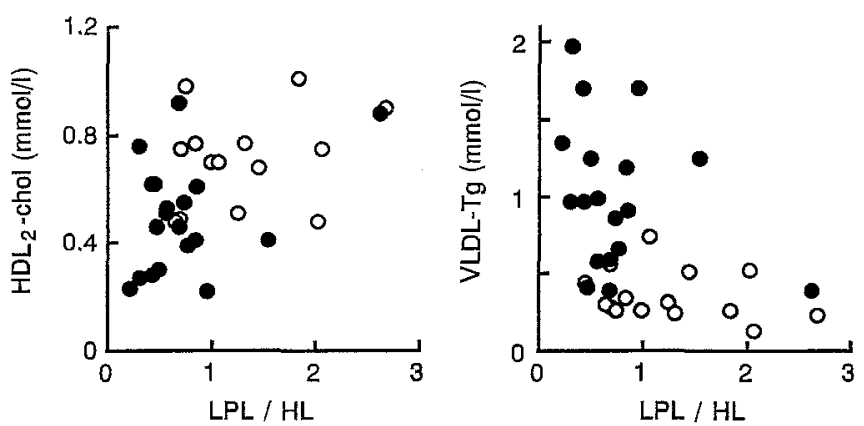

Fig. 2. Univariable correlation between the lipoprotein lipase - hepatic lipase ratio and VLDL-triglycerides in the right panel $(r=-0.44, p<0.05)$; and with $\mathrm{HDL}_{2}$-cholesterol in the left panel $(r=0.47, p<0.01)$. O subjects in the low-insulin group; - in the high-insulin group

concentration of $\mathrm{HDL}$ particles containing only apo A-I (LpA-I particles) was reduced by $21 \%$ in the high insulin group as compared to the low insulin group ( $39 \pm 8$ vs $48 \pm 9 \mathrm{mg} / \mathrm{dl}, p<0.05$ ). The concentration of LpA-I:A-II particles was slightly lower in the high insulin group compared to the low insulin group ( $89 \pm 7$ vs $99 \pm 13 \mathrm{mg} / \mathrm{dl}, p<0.05$ ). No differences in total and LDL cholesterol (Table 2) or apolipoprotein B levels $(113 \pm 28$ vs $94 \pm 28 \mathrm{mg} / \mathrm{dl}$, NS) were observed between the two groups. Despite similar concentrations of LDL cholesterol the particle diameter of the major LDL peak was significantly smaller in the high insulin group as compared to the low insulin group ( $258 \pm 7$ vs $265 \pm 6 \AA, p<0.05$ ). If, however, adjusted for BMI, the difference between the two groups is no longer statistically significant $(p=0.130)$. Individual values for post-heparin plasma LPL and HL activities are shown in Fig. 1. In the high insulin group the mean value of LPL activity was moderately reduced (by $29 \%$ ) as compared to the low insulin group (14.2 \pm 4.0 vs $20.0 \pm 5.8 \mu \mathrm{mol}$ NEFA $\left.\cdot \mathrm{ml}^{-1} \cdot \mathrm{h}^{-1}, p<0.001\right)$. As shown in Fig. 1 there was clear overlap of individual values between the two groups. The difference remained significant when LPL activity was adjusted for BMI. Post-heparin plasma HL activity did not differ significantly between the two groups $(24.2 \pm 11$ vs $18.0 \pm 5.3 \mu \mathrm{mol}$ $\left.\mathrm{NEFA} \cdot \mathrm{ml}^{-1} \cdot \mathrm{h}^{-1}, p=0.11\right)$. LPL/HL ratio was markedly lower in the high than the low insulin group $(0.75 \pm 0.57$ vs $1.25 \pm 0.65, p<0.01)$. In the study group as a whole LPL activity correlated negatively with VLDL triglyceride $(r=-0.475, p<0.01)$ but positively with $\mathrm{HDL}_{2}$ cholesterol $(r=0.479$, $p<0.01)$. There was a weak inverse association between $\mathrm{HL}$ activity and $\mathrm{HDL}_{2}$ triglycerides $(r=$ $-0.352, p<0.05$ ). As expected LPL/HL ratio correlated inversely with VLDL triglyceride but positively with $\mathrm{HDL}_{2}$ cholesterol concentration (Fig. 2). In the whole study group there was an inverse association between fasting insulin and post-heparin plasma LPL activity $(r=-0.510, p<0.01)$. No association was observed between fasting insulin levels and HL activity.

\section{Discussion}

Two important findings emerged from the present study. First, the data suggest that low levels of postheparin plasma LPL activity as well as that of LPL/ HL ratio cluster with insulin resistance in healthy normoglycaemic first-degree relatives of NIDDM patients. A second significant feature is that the reduction in LPL activity and LPL/HL ratio was accompanied by elevation of triglycerides, decrease in HDL cholesterol and preponderance of small dense LDL. Since LPL is the key enzyme in the catabolism of triglyceride-rich particles, and on the other hand LPL and HL have opposite actions on the plasma concentration of HDL, it is tempting to speculate that changes of LPL and more particularly those of LPL/ $\mathrm{HL}$ ratio in insulin-resistant subjects may contribute to both the decrease in HDL cholesterol and to the increase in triglycerides.

The fact that post-heparin LPL activity was reduced in subjects with high insulin levels is consistent with earlier observations suggesting that insulin resistance may influence LPL activity [23, 45]. Substantial evidence has emerged that the response of LPL in post-heparin plasma and in adipose tissue is unresponsive to insulin action in obesity and in NIDDM $[22,46,47]$. The studies by Pollare et al. [23] provided more direct evidence for the association between insulin resistance and LPL activity. Pollare et al. [23] reported a positive correlation between muscle LPL activity and glucose infusion rate indicating that hyperinsulinaemia actually downregulated muscle LPL activity. We have previously shown that in a healthy non-diabetic population post-heparin plasma LPL activity is closely correlated with LPL activity in both adipose tissue and skeletal muscle [48]. Thus 
changes of post-heparin LPL activity reflect those of LPL in both tissues. In this study we measured LPL activity in post-heparin plasma but not in tissues. Therefore, our data do not allow us to conclude whether the decrease in plasma LPL activity reflects a decrease in both adipose tissue and/or only in skeletal muscle.

The mechanisms whereby insulin resistance and/or hyperinsulinaemia downregulates LPL activity are unknown. Interestingly, the data by Peterson et al. [49] indicate that NEFA can dissociate LPL from its binding sites and lead to a rapid degradation of the enzyme [50]. Accordingly, it has been proposed that circulating NEFA may have a feed-back control on LPL activity at the endothelial site. Although we did not measure NEFA levels in this study, available data indicate that insulin-mediated suppression of lipolysis is impaired in insulin-resistant states as well as in glucose-tolerant relatives of NIDDM patients $[30,51-53]$. Heterozygous carriers of a defective LPL gene with reduced LPL activity have normal fasting triglyceride levels but demonstrate fat intolerance [54]. Interestingly, Miesenböck et al. [54] reported that in carriers affected by a missense mutation at codon 188 of the LPL gene, the concentration of VLDL triglycerides was higher and that of HDL and $\mathrm{HDL}_{2}$ cholesterol lower than in non-carriers from the same pedigree. Thus, the phenotype resembled that of the men with high fasting insulin levels in this study. Although multiple genetic defects of LPL have been identified they are rare and hardly explain the lowering of LPL activity in our unrelated men with high insulin levels.

The actual difference of LPL activities in the two groups was only moderate and there was considerable overlap of individual values. However, in the presence of VLDL overproduction as occurs in insulin resistance and in NIDDM due to enhanced NEFA flux into the liver [14] even trivial defects in LPL action would aggravate the elevation of serum triglycerides. In addition compositional changes of secreted VLDL can also modify its characteristics as a substrate for LPL and thus impede the lipolytic process. Thus these dual abnormalities can contribute in concert to the elevation of serum triglycerides. In general, increase of serum triglycerides is accompanied by lowering of HDL cholesterol. These reciprocal changes are partly explained by the action of LPL which also determines plasma HDL, particularly $\mathrm{HDL}_{2}$ concentrations [24]. Accordingly, in the insulin-resistant men of the present study we observed concomitant but opposite changes of VLDL triglyceride and $\mathrm{HDL}_{2}$ together with lowering of LPL activity. Recently, Blades et al. [28] reported that lowering of LPL/HL ratios was a significant contributor to low HDL syndrome. Interestingly the HDL lowering action of elevated $\mathrm{HL}$ activity was more pronounced in subjects with subnormal LPL activity. Likewise Brin- ton et al. [55] have enforced LPL/HL ratio i. e. co-ordinate opposite action of the two enzymes, as a determinant of HDL size, its fractional removal rate and consequently its plasma concentration. Although in our study we failed to show any significant difference in the HL activities between the high and low insulin groups the LPL/HL ratio was reduced by $67 \%$. The observed lowering of LpA-I particles in men with high insulin is consistent with the data indicating that the majority of LpA-I particles reside within $\mathrm{HDL}_{2}$ density range [56]. Likewise the concentration of apoA-I, which was measured by an independent assay, was reduced in men with high insulin, further confirming the observation that the lowering of $\mathrm{HDL}$ is caused by that of $\mathrm{HDL}_{2}$ particles. The data agree well with a recent report by Montali et al. [57] that there is a preferential reduction of LpA-I particles in patients with hypoalphalipoproteinaemia. The prolonged residence time of VLDL particles would promote core lipid exhange between lipoproteins $[58,59]$. Triglyceride enrichment of LDL and HDL in the presence of high HL activity would drive the formation of small dense LDL and lowering of $\mathrm{HDL}_{2}$ fraction [60]. The particle diameter of the major LDL peak was significantly lower in men with high insulin than in men with low insulin.

In conclusion, our results show that low levels of LPL activity and LPL/HL ratio cluster with insulin resistance in normoglycaemic first-degree relatives of NIDDM patients. We propose that low levels of LPL and LPL/HL ratio provide a possible mechanism to explain the lowering of HDL cholesterol and elevation of triglyceride concentrations observed in insulin-resistant subjects.

Acknowledgements. We thank physicians B.Forsén, B. Snickars and B.-O.Ehrnström from the Botnia Study Group. We also thank Ms. M. Gullström, Ms. M. Lindfors and Ms. S.Salmela for their assistance in patient care; and Ms. H. Hildén, Ms. S. Rannikko and Ms. S.-L. Runeberg for their technical assistance. This work was supported by grants from the Sigrid Juselius Foundation and the Meilahti Foundation, Helsinki, Finland.

\section{References}

1. Reaven GM (1988) Banting lecture 1988: role of insulin resistance in human disease. Diabetes 37: 1595-1607

2. DeFronzo RA, Ferrannini E (1991) Insulin resistance. A multifaceted syndrome responsible for NIDDM, obesity, hypertension, dyslipidemia and atherosclerotic cardiovascular disease. Diabetes Care 14: 173-194

3. Haffner SM, Valdez RA, Hazuda HP, Braxton DM, Morales PA, Stern MP (1992) Prospective analysis of the insulin-resistance syndrome (syndrome X). Diabetes 41: 715-722

4. Selby JV, Austin MA, Newman B et al. (1993) LDL subclass phenotypes and the insulin resistance syndrome in women. Circulation 88: 381-387

5. Reaven GM, Chen Y-DI, Jeppesen J, Maheux P, Krauss RM (1993) Insulin resistance and hyperinsulinemia in indi- 
P. Knudsen et al.: Changes of lipolytic enzymes cluster with insulin resistance syndrome

viduals with small, dense, low density lipoprotein particles. J Clin Invest 92: 141-146

6. Austin MA, King M-C, Vranizan KM, Krauss (1990) Atherogenic lipoprotein phenotype. A proposed genetic marker for coronary heart disease risk. Circulation 82 : 495-506

7. Campos H, Genest JJ Jr, Blijlevens E et al. (1992) Low density lipoprotein particle size and coronary artery disease. Arteriosclerosis 12: 187-195

8. Reaven GM, Lerner RL, Stern MP, Farquhar JW (1967) Role of insulin in endogenous hypertriglyceridemia. J Clin Invest 46: 1756-1767

9. Orchard T, Becker DJ, Bates M, Kuller LH, Drash AL (1983) Plasma insulin and lipoprotein concentrations: an atherogenic association? Am J Epidemiol 118: 326-337

10. Abbot WGH, Lillioja S, Young AA et al. (1987) Relationship between plasma lipoprotein concentrations and insulin action in an obese hyperinsulinemic population. Diabetes 36: 897-904

11. Mykkänen L, Kuusisto J, Pyörälä K, Laakso M (1993) Cardiovascular disease factors as predictors of type 2 (non-insulin-dependent) diabetes mellitus in elderly subjects. Diabetologia 36: 553-559

12. Garg A, Heldermann JH, Koffler M, Ayosos R, Rosenstock $\mathbf{J}$ (1988) Relationship between lipoprotein levels and in vivo insulin action in normal young white men. Metabolism 37: 982-987

13. Yki-Järvinen H, Taskinen M-R (1988) Interrelationships among insulin's antilipolytic and glucoregulatory effects and plasma triglycerides in nondiabetic and diabetic patients with endogenous hypertriglyceridemia. Diabetes 37 : 1271-1278

14. Taskinen M-R (1990) Hyperlipidemia in diabetes. Baill Clin Endocrinol Metab 4: 743-775

15. Sparks JD, Sparks CE (1990) Insulin modulation of hepatic synthesis and secretion of apolipoprotein B by rat hepatocytes. J Biol Chem 265: 8854-8862

16. Gibbons GF (1990) Assembly and secretion of hepatic very-low-density lipoprotein. Biochem J 268: 1-13

17. Frayn KN (1993) Insulin resistance and lipid metabolism. Curr Opinion Lipidol 4: 197-204

18. Lewis GF, Uffelman KD, Szeto LW, Steiner G (1993) Effects of acute hyperinsulinemia on VLDL triglyceride and VLDL apoB production in normal weight and obese individuals. Diabetes 42: 833-842

19. Pykälistö OJ, Smith PH, Brunzell JD (1975) Determinants of human adipose tissue lipoprotein lipase. Effect of diabetes and obesity on basal- and diet-induced activity. J Clin Invest 56: 1108-1117

20. Ong JM, Kern PA (1989) Effect of feeding and obesity on lipoprotein lipase activity, immunoreactive protein and messenger RNA levels in human adipose tissue. J Clin Invest $84: 305-311$

21. Eckel RH (1989) Lipoprotein lipase. A multifunctional enzyme relevant to common metabolic diseases. N Engl J Med 320: 1060-1068

22. Coppack SW, Evans RD, Fisher RM et al. (1992) Adipose tissue metabolism in obesity: lipase action in vivo before and after a mixed meal. Metabolism 41: 264-272

23. Pollare T, Vessby B, Lithell H (1991) Lipoprotein lipase activity in skeletal muscle is related to insulin sensitivity. Arteriosclerosis 11: 1192-1203

24. Taskinen M-R, Kuusi T (1987) Enzymes involved in triglyceride hydrolysis. Baill Clin Endocrinol Metab 1: 639-666

25. Harno K, Nikkilä EA, Kuusi T (1980) Plasma HDL-cholesterol and postheparin plasma hepatic endothelial lipase (HL) activity: relationship to obesity and non-insulin de- pendent diabetes (NIDDM). Diabetologia 19: 281 (Abstract)

26. Kasim SE, Kingston T, Jen K-LC, Khilnani S (1987) Significance of hepatic triglyceride lipase activity in the regulation of serum high density lipoproteins in type II diabetes mellitus. J Clin Endocrinol Metab 65: 183-187

27. Baynes C, Henderson AD, Anyaoku V et al. (1991) The role of insulin insensitivity and hepatic lipase in the dyslipidaemia of type 2 diabetes. Diabet Med 8: 560-566

28. Blades B, Vega GL, Grundy SM (1993) Activities of lipoprotein lipase and hepatic lipase in postheparin plasma of patients with low concentrations of HDL cholesterol. Arteriosclerosis 13: $1227-1235$

29. Lamarche B, Despres J-P, Pouliot M-C et al. (1993) Metabolic heterogeneity associated with high plasma triglyceride or low HDL cholesterol levels in men. Arteriosclerosis 13: $33-40$

30. Laws A, Stefanick L, Reaven GM (1989) Insulin resistance and hypertriglyceridemia in nondiabetic relatives of patients with noninsulin dependent diabetes mellitus. J Clin Endocrinol Metab 69: 343-347

31. Eriksson J, Franssila-Kallunki A, Ekstrand A, Saloranta C, Widen E, Schalin C, Groop L (1989) Early metabolic defects in persons at increased risk for non-insulin-dependent diabetes mellitus. N Engl J Med 321: 337-343

32. Gulli G, Ferrannini E, Stern E, Haffner S, DeFronzo RA (1992) The metabolic profile of NIDDM is fully established in glucose-tolerant offspring of two Mexican-American NIDDM parents. Diabetes 41: 1575-1586

33. Laakso M (1993) How good a marker is insulin level for in sulin resistance? Am J Epidemiol 137: 959-965

34. Sarlund H, Pyörälä K, Penttilä I, Laakso M (1992) Early abnormalities in coronary heart disease risk factors in relatives of subjects with non-insulin-dependent diabetes. Arteriosclerosis 12: 657-663

35. World Health Organization (1985) Diabetes mellitus. Report of a WHO Study Group, Geneva. Technical Report Series no. 727

36. Havel RJ, Eder HA, Brigdon JH (1956) The distribution and chemical composition of ultracentrifugally separated lipoproteins in human serum. J Clin Invest 34: 1345-1353

37. Taskinen M-R, Kuusi T, Helve E, Nikkilä EA, Yki-Järvinen $H$ (1988) Insulin therapy induces antiatherogenic changes of serum lipoproteins in noninsulin-dependent diabetes. Arteriosclerosis 8: 168-177

38. Huttunen JK, Ehnholm CJ, Kinnunen PKJ, Nikkilä EA (1975) An immunochemical method for the selective measurement of two triglyceride lipases in human postheparin plasma. Clin Chim Acta 63: 335-347

39. Parra HJ, Mezdour H, Ghalim N, Bard JM, Fruchart JC (1990) Differential electroimmunoassay of human LpA-I lipoprotein particles on ready to-use plates. Clin Chem 36: 1431-1435

40. Kahri J, Groop P-H, Viberti G, Elliott T, Taskinen M-R (1993) Regulation of apolipoprotein A-I- containing lipoproteins in IDDM. Diabetes 42: 1281-1288

41. Nichols AV, Krauss RM, Musliner TA (1986) Nondenaturating polyacrylamide gradient gel electrophoresis. In: Segrest JP, Albers JJ (eds) Methods in enzymology: Plasma lipoproteins (vol 128). Academic Press, London, pp 417 431

42. Margolis J, Kenrick KG (1967) Electrophoresis in polyacrylamide concentration gradient. Biochem Biophys Res Comm 27: 68-73

43. Polyacrylamide gel electrophoresis 1984 Laboratory techniques. Pharmacia, Laboratory separation division, Uppsala, Sweden, pp 16-20 
44. Tilly-Kiesi M, Syvänne M, Kuusi T, Lahdenperä S, Taskinen M-R (1992) Abnormalities of low density lipoproteins in normolipidemic type 2 diabetic and non-diabetic patients with coronary artery disease. J Lipid Res 33: 333-342

45. Kern PA, Ong JM, Saffari B, Carty J (1990) The effects of weight loss on the activity and expression of adipose-tissue lipoprotein lipase in very obese humans. $\mathrm{N}$ Engl $\mathrm{J}$ Med 322: 1053-1059

46. Taylor KG, Dalton DJ, Holdsworth G (1979) Insulin-independent diabetes: a defect in the activity of lipoprotein lipase in adipose tissue. Diabetologia 16: 313-317

47. Sadur CN, Yost TJ, Eckel RH (1984) Insulin responsiveness of adipose tissue lipoprotein lipase is delayed but present in obesity. J Clin Endocrinol Metab 59: 1176-1182

48. Taskinen M-R (1987) Lipoprotein lipase in hypertriglyceridemias. In: Borensztajn J (ed): Lipoprotein lipase. Evener Publishers, Inc. Chicago, pp 201-228

49. Peterson J, Bihain BE, Bengtsson-Olivecrona G, Deckelbaum RJ, Carpentier YA, Olivecrona T (1990) Fatty acid control of lipoprotein lipase: a link between energy metabolism and lipid transport. Proc Natl Acad Sci U.S. A. 87: 909-913

50. Saxena U, Goldberg IJ (1990) Interaction of lipoprotein lipase with glycosaminoglycans and apolipoprotein C-II: effects of free-fatty-acids. Biochim Biophys Acta 1043: 161168

51. Golay A, Chen YD, Reaven GM (1986) Effect of differences in glucose tolerance on insulin's ability to regulate carbohydrate and free fatty acid metabolism in obese individuals. J Clin Endocrinol Metab 62: 1081-1088

52. Groop LC, Saloranta C, Shank M, Bonadonna RC, Ferrannini E, De Fronzo RA (1991) The role of free fatty acid metabolism in the pathogenesis of insulin resistance in obesity and non-insulin-dependent diabetes mellitus. J Clin Endocrinol Metab 72: 96-107

53. Coppack SW, Jensen MD, Miles JM (1994) In vivo regulation of lipolysis in humans. J Lipid Res 35: 177-193

54. Miesenböck G, Hölzl B, Föger B et al. (1993) Heterozygous lipoprotein lipase deficiency due to a missense mutation as the cause of impaired triglyceride tolerance with multiple lipoprotein abnormalities. J Clin Invest 91: 448-455

55. Brinton EA, Eisenberg S, Breslow J (1994) Human HDL cholesterol levels are determined by apoA-I fractional catabolic rate, which correlates inversely with estimates of HDL particle size. Arterioscler Thromb 14: 707-720

56. James RW, Pometta D (1990) Immunofractionation of high density lipoprotein subclasses 2 and 3 . Similarities and differences of fractions isolated from male and female populations. Atherosclerosis 83: 35-45

57. Montali A, Vega GL, Grundy SM (1994) Concentrations of apolipoprotein A-I-containing particles in patients with hypoalphalipoproteinemia. Arteriosclerosis 14: 511-517

58. Deckelbaum RJ, Granot E, Oschry Y, Rose L, Eisenberg S (1984) Plasma triglyceride determines structure-composition in low and high density lipoproteins. Arteriosclerosis 4: 225-231

59. Lagrost L, Gandjini H, Athias A, Guyard-Dangremont V, Lallemant C, Gambert P (1993) Influence of plasma cholesteryl ester transfer activity on the LDL and HDL distribution profiles in normolipidemic subjects. Arteriosclerosis 13: $815-825$

60. Patsch JR, Prasad S, Gotto AM Jr, Patsch W (1987) High density lipoprotein ${ }_{2}$. Relationship of the plasma levels of this lipoprotein species to its composition, to the magnitude of postprandial lipemia and to the activities of lipoprotein lipase and hepatic lipase. J Clin Invest 80: 341-347 